[13] Commission Regulation 466/2001 of 8 March 2001 fixing maximum levels for certain contaminants in foodstuffs. Available at: https://op.europa.eu/en/publication-detail/-/publication/89680896-d084-4f35-8340-13e8b4f59f08/language-en

[14] Kharchovi dobavky. Nomenklatura ta zahalni vymohy: DSTU-N CODEX STAN 192:2009 (2009). Kyiv: Ukrderzhspozhyvstandart Ukrainy, 246.

\title{
SUBSTANTIATION OF THE CHOICE OF FILLERS FOR COTTAGE CHEESE MASSES
}

\author{
Marina Samily $\boldsymbol{k}^{1}$ \\ m.samilyk@ukr.net \\ Anna Helikh ${ }^{1}$ \\ gelihsumy@gmail.com \\ Natalia Bolgova ${ }^{1}$ \\ bolgova_1981@i.ua \\ Taisia Ryzhkova \\ Kharkiv State Zooveterinary Academy \\ 1 Akademichna str., Mala Danylivka, Dergachivsky district, Kharkiv region, Ukraine, 62341 \\ rujkova.ua@gmail.com \\ Igor Sirenko ${ }^{1}$ \\ igorsirenko5@gmail.com \\ Oleg Fesyun ${ }^{1}$ \\ oleg.takert@gmail.com \\ ${ }^{1}$ Sumy National Agrarian University \\ 160 Gerasim Kondratyev str., Sumy, Ukraine, 40000
}

\footnotetext{
Abstract

The aim of this work is to justify the use of candied fruits as fillers in the production of curd and to study their influence on the quality indicators of the finished product. The article presents studies of the organoleptic, physicochemical, structural and mechanical properties of the curd masses depending on the type of fillers. Curd recipes have been developed with candied parsnip in the amount of $10 \%$, candied parsnip in the amount of $15 \%$, candied pumpkin in the amount of $10 \%$, candied pumpkin in the amount of $15 \%$. Experimental studies have determined the optimal dose of candied fruits from parsnip and pumpkin, which is $150 \mathrm{~kg}$ per $1000 \mathrm{~kg}$ of the product.

The chemical composition of pumpkin and parsnip is analyzed, the feasibility of using candied fruit from them as fillers is substantiated. In order to preserve the maximum amount of vitamins in candied fruit, a technology for their production has been developed, including cooking in sugar syrup using low temperatures $\left(60^{\circ} \mathrm{C}\right)$ and further drying by the convection-vacuum method at a temperature of $50{ }^{\circ} \mathrm{C}$.

It has been established, that all types of fillers that took part in the experiments do not adversely affect the physicochemical and rheological properties of the curd mass. It has been proven, that candied parsnip and pumpkin positively affect the density of the curd mass structure and provide the plastic structure of the product.

Keywords: cottage cheese, cottage cheese, candied fruit, parsnip, pumpkin, recipe, vitamins, carotene, structure density, sucrose content.
} 


\section{Introduction}

The main component of the curd mass is cottage cheese, which during its production is not amenable to heat treatment, which allows you to save all its useful properties. Cottage cheese is a source of $\mathrm{B}$ vitamins $\left(\mathrm{B}_{2}, \mathrm{~B}_{3}, \mathrm{~B}_{12}\right)$, proteins, fats, calcium, phosphorus and other equally important nutrients.

Curd mass can be used as a ready-to-eat dessert, and also as a raw material in the manufacture of a variety of products. Most often, fruit and berry, vegetable and confectionery fillers are used as additives that add a certain taste to the production of sweet curd masses.

Current technologies are those, using vegetable raw materials, which allow enriching dairy products with natural vitamins, pectins, minerals, as well as natural coloring agents $[1,2]$.

The effect of pine nuts on the quality and biological value of the curd and plant mass has been investigated and the possibility of obtaining a curd product with predetermined dietary and therapeutic properties has been brought up $[3,4]$.

It is proposed to use sesame seeds to enrich the curd with protein, calcium and polyunsaturated fatty acids. It has been established, that by combining raw materials of animal and plant origin, the biological value of the protein of the enriched product increases, and the amino acid composition is balanced [5]. But in the works of these scientists, the moments of the influence of components on the structure of dairy products are not shown. And the structure is the most important indicator of quality.

In addition, many studies are aimed at using a wide range of traditional and new food additives, which are stabilizers, that is they form the structure of the dairy product $[6,7]$.

Improving the quality and safety, increasing the yield, enriching it with food additives and functional ingredients is an important direction in the development of the technology of cottage cheese products [8-10].

Scientists have proposed enriching dairy products with date fibers and have shown an improvement in their nutritional value. Introduction to dairy products to improve the nutritional value of only dietary fiber has a rather narrow focus in the aspect of enrichment. And candied fruits, except for pectin, have a number of useful substances: vitamins, minerals, etc. [11]. The main source of carbohydrates, vitamins, mineral salts, volatile and dietary fiber, necessary for the normal functioning of a living organism, are vegetables [11]. Therefore, many scientists are exploring all sorts of ways to use them in food production [11].

Teachers of Lviv National University of Veterinary Medicine and Biotechnology, named after S. Z. Gzhitsky developed the technology of candied pumpkin with lemon balm and proposed an improved technology for the production of curd products [12]. However, their research is aimed at studying the physicochemical composition of curd products. In addition, the candied fruit production technology is different.

The results of experimental data indicate that candied fruits, obtained from fresh vegetables, have high organoleptic characteristics [13]. The presented technology for obtaining candied fruits does not allow to fully preserve all the nutritional properties of vegetables. Employees of Sumy National Agrarian University proposed a technology for making candied fruit by the method of osmotic dehydration, which allows them to preserve their nutritional value as much as possible [13].

The research by Polish scientists is aimed at developing new cottage cheese with increased biological value and increased shelf life by adding fresh or dried parsley, dill, pepper, garlic and rosemary. The characteristics of phenolic compounds, antioxidant ability, and antibacterial activity of spices and cheese samples were evaluated. However, studies of the physicochemical composition of the developed cottage cheese are not presented [14].

Among vegetables that can be used in food production, parsnip is of particular interest. Parsnip root crops contain 20-34 \% of dry matter, 1.8-3.1 - protein, 7.4-12 - sugar, 0.38 - fat, 1.2-3.6fiber, $1-1.6 \%$ ash. The value of parsnip lies in the favorable ratio of minerals. The content in $100 \mathrm{~g}$ of root crops is: sodium $-8 \mathrm{mg}$, potassium -469 , magnesium -22 , calcium -51 , iron -0.62 , phosphorus $-73 \mathrm{mg}$. Compared to other vegetables, it has a high content of essential oils, which have an exciting effect on the body, add food with a pleasant aroma. Root crops contain vitamins: carotene $-0.02 \mathrm{mg} / 100 \mathrm{~g}, \mathrm{~B}_{1}-0.08, \mathrm{~B}_{2}-0.13, \mathrm{C}-$ from 9.3 to $30, \mathrm{PP}-0.94, \mathrm{~B}_{6}-0.11 \mathrm{mg} / 100 \mathrm{~g}$ [15]. 
The technology of fermented milk products with candied parsnip has not been studied before. Therefore, the presented studies are relevant and timely.

An analysis of the literature showed the unresolved issue of developing the optimal manufacturing technology for candied fruit vegetables, which allows to preserve the vitamin content in them as much as possible. In our research, we propose a way to solve this problem.

The aim of this work is to justify the use of candied fruits as fillers in the production of curd and to study their influence on its physicochemical characteristics.

To achieve the goal, the following tasks were set:

- develop a recipe for the curd mass with candied fruit and determine the optimal amount of fillers by organoleptic evaluation;

- explore the chemical composition of pumpkin and parsnip, justify the feasibility of their use as fillers;

- determine the physicochemical characteristics of the products and analyze their dependence on the type and amount of fillers;

- analyze the effect of fillers on the density of the structure of the curd mass.

\section{Materials and methods}

The cottage cheese recipe is selected according to the technological instructions for obtaining the finished product in accordance with the requirements of DSTU 4503:2005 "Cottage cheese products. General technical conditions" [16]. As a control sample, the recipe for the curd sweet "Special" mass with candied fruit was selected [17]. For preparation of the control sample, candied Pineapple of the Silk Way trademark (Ukraine) was used. Four samples of cottage cheese with candied parsnip and pumpkin were simultaneously prepared (Table 1).

Table 1

Cottage cheese recipes with candied fruit (in $\mathrm{kg}$ per $1000 \mathrm{~kg}$ of product, excluding losses)

\begin{tabular}{|c|c|c|c|c|c|}
\hline \multirow{3}{*}{ Row materials } & Control & Sample 1 & Sample 2 & Sample 3 & Sample 4 \\
\hline & With candied "Pineapple" & \multicolumn{2}{|c|}{ With candied parsnip } & \multicolumn{2}{|c|}{ With candied pumpkin } \\
\hline & $\mathbf{K}$ & S1 & $\mathbf{S 2}$ & S3 & S4 \\
\hline $\begin{array}{l}\text { Cottage cheese with a mass fraction of } \\
\text { fat } 18 \%\end{array}$ & 528.75 & 528.75 & 713.85 & 528.75 & 713.85 \\
\hline $\begin{array}{l}\text { Butter with a mass fraction of } \\
\text { fat } 82.5 \% \text {, moisture } 16 \%\end{array}$ & 136.10 & 136.10 & 136.10 & 136.10 & 136.10 \\
\hline Sugar & 235.10 & 235.10 & - & 235.10 & - \\
\hline Vanillin & 0.05 & 0.05 & 0.05 & 0.05 & 0.05 \\
\hline Candied products & 100.0 & 100.0 & 150.0 & 100.0 & 150.0 \\
\hline Complete & 1000 & 1000 & 1000 & 1000 & 1000 \\
\hline
\end{tabular}

Candied parsnip and pumpkin were made in the training laboratory of the department of milk and meat technology of Sumy National Agrarian University. In order to preserve the maximum amount of vitamins in them, a technology has been developed for the production of candied fruits from vegetables by osmotic dehydration in sugar syrup at low temperatures $\left(50^{\circ} \mathrm{C}\right)$ and further drying by the convective-vacuum method at a temperature of $50{ }^{\circ} \mathrm{C}$. Candied fruit samples are presented in Fig. 1.

The organoleptic characteristics of the curd mass were evaluated on a 5-point scale. The following indicators were controlled: taste, smell, color, consistency, appearance, which were assigned a quantitative expression in points.

The acidity of the experimental samples of the curd mass was determined by the titrimetric method in accordance with GOST 3624-92.

The mass content of sucrose was determined in accordance with GOST 3628, the mass content of moisture in accordance with GOST 3626. 


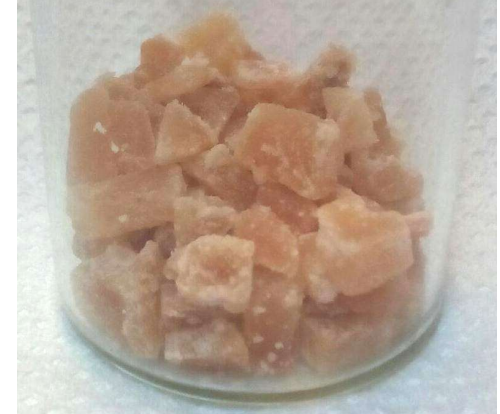

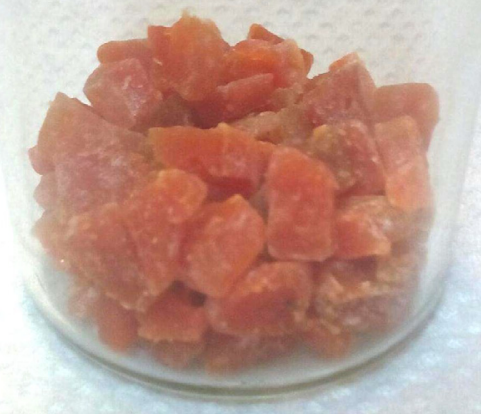

$b$

Fig. 1. Candied fruits from vegetables: $a$ - from parsnip, $b$ - from pumpkin

To assess the density of the structure of the curd mass using a penetrometer, the immersion depth of the cone was found and the boundary shear stress was calculated by the formula. The shear boundary stress (GNS) of an unbroken structure $\sigma 0(\mathrm{~Pa})$ is calculated using the Rebinder formula:

$$
\sigma_{0}=k \frac{m \cdot g}{h^{2}}
$$

where $m$ - the mass of the indenter and the rod of the device, which acts on the test product (taking into account the difference in friction and resistance of the indenter spring), $\mathrm{kg} ; g$ - the acceleration of gravity, $\mathrm{m} / \mathrm{s}^{2} ; h$ - the immersion depth of the cone, $\mathrm{m} ; k$ - the indenter constant. The results are presented as the arithmetic mean of five measurements $(n=5)$, taking into account the standard deviation $(P=0.95 \%)$.

\section{Results}

According to the proposed recipes, the following experimental samples were made with candied "Pineapple", candied parsnip and pumpkin.

A distinctive feature of all vegetables and root crops is a fairly high content of vitamins, sugars, aromatic, pectin and minerals. In addition, parsnip contains glycosides and phenolic substances that give it a unique taste, aroma and exhibits antimicrobial and fungicidal effects [18].

Organoleptic characteristics of the product must meet the requirements (used GOST Cottage mass "Special". Technical conditions), which are presented in Table 2.

\section{Table 2}

Characterization of organoleptic indicators of cottage cheese

\begin{tabular}{ll}
\hline \multicolumn{1}{c}{ Name of indicator } & \multicolumn{1}{c}{ Characteristic } \\
\hline Consistency and appearance & Homogeneous, moderately dense, with visible or tangible presence of introduced components \\
Taste and smell & Pure, sour-milk, sweet, with a touch of added ingredients \\
Color & White, creamy white or color-coded
\end{tabular}

In this Table 2, the characteristic of organoleptic indicators was used in accordance with GOST 31680-2012.

Organoleptic evaluation was carried out on a 5 point scale. The results of the organoleptic evaluation of the experimental samples are presented in the form of profilograms (Fig. 2).

The simultaneous use of candied fruits and sugar turned out to be ineffective, since this gives the curd mass too sweet taste. The consistency, appearance, color and smell of all samples were marked by the highest rating ( 5 points), however, the results of the taste assessment were different. The highest rating (5 points) was in a sample that contained $150 \mathrm{~g}$ of candied parsnip (S2). A sample that contained $100 \mathrm{~g}$ of candied pumpkin (S3) was marked with the lowest score (4.7) because it was too sweet. Although the taste of the curd mass, containing $100 \mathrm{~g}$ of candied parsnip, 
was rated at 4.8 points, this is because pumpkin contains more sugars. Thus, when using $150 \mathrm{~g}$ of candied fruit, sugar can be excluded from the recipe.

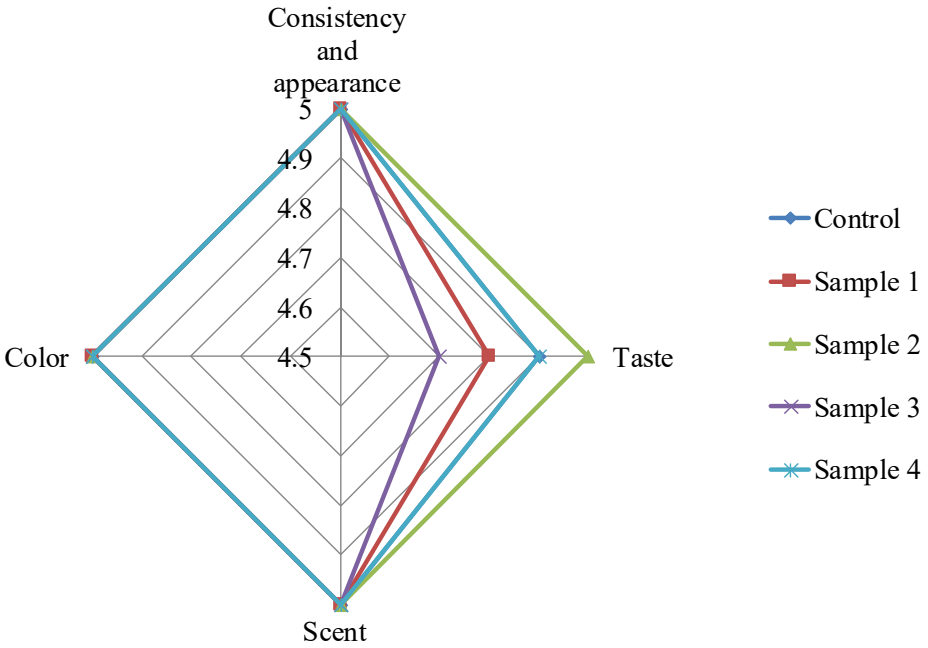

Fig. 2. Profilogram of organoleptic indicators

In accordance with the objectives of the research, we consider it appropriate to leave such a structure, and present the results in this sequence.

A distinctive feature of all vegetables and root crops is a fairly high content of vitamins, sugars, aromatic, pectin and minerals. In addition, parsnip contains glycosides and phenolic substances that give it a unique taste, aroma and exhibits antimicrobial and fungicidal effects [18].

The comparative characteristics of the chemical composition of parsnip and pumpkin, according to the results of known studies [12-15], are presented in Table 3.

Table 3

The chemical composition of the fillers (per $100 \mathrm{~g}$ of product)

\begin{tabular}{|c|c|c|c|}
\hline Indicators & Daily intake & Parsnip content & Pumpkin Content \\
\hline \multicolumn{4}{|c|}{ Nutritional value (g) } \\
\hline Proteins & 90 & 3.1 & 1 \\
\hline Fats & 70 & 0.38 & 0.1 \\
\hline Carbohydrates & 300 & 7.4 & 4.4 \\
\hline Nutritional value & 25 & 4.5 & 2 \\
\hline Calorie content & $\mathrm{kCal}$ & 47 & 22 \\
\hline \multicolumn{4}{|c|}{ Vitamins (mg) } \\
\hline $\mathrm{B}_{1}$ (thiamine) & 1.5 & 0.08 & 0.05 \\
\hline $\mathrm{B}_{2}$ (riboflavin) & 2 & 0.13 & 0.06 \\
\hline $\mathrm{B}_{3}($ niacin $)$ & 20 & 0.94 & 0.7 \\
\hline $\mathrm{B}_{5}$ (pantothenic acid) & 10 & 0.6 & 0.4 \\
\hline $\mathrm{B}_{6}($ pyridoxine $)$ & 2 & 0.11 & 1.6 \\
\hline$\beta$-carotene & 2.5 & 0.02 & 1.5 \\
\hline $\mathrm{B}_{9}$ (folic acid) & 400 & 0,067 & 0,014 \\
\hline $\mathrm{C}$ (ascorbic acid) & 60 & 30 & 8 \\
\hline \multicolumn{4}{|c|}{ Minerals (mg) } \\
\hline $\mathrm{Na}$ & 1300 & 8 & 4 \\
\hline $\mathrm{K}$ & 2000 & 342 & 204 \\
\hline $\mathrm{Ca}$ & 1150 & 57 & 25 \\
\hline $\mathrm{Mg}$ & 400 & 22 & 14 \\
\hline $\mathrm{P}$ & 1200 & 73 & 25 \\
\hline $\mathrm{Fe}$ & 15 & 0.7 & 0.4 \\
\hline
\end{tabular}


After analyzing the chemical composition of the fillers, it can be noted, that the nutritional value of parsnip is by $50 \%$ higher than the nutritional value of pumpkin, and the protein content in it exceeds three times. The mineral composition of both fillers is characterized by the presence of salts of magnesium, phosphorus, calcium, iron, sodium and potassium. The daily intake of minerals is not balanced, but parsnip contains more than pumpkin: sodium by $50 \%$, potassium by $40 \%$, calcium by $66 \%$, magnesium by $46 \%$, phosphorus by $66 \%$, and iron by $43 \%$.

Parsnip and pumpkin are a good source of vitamins. Pumpkin has antioxidant properties, contains $1.5 \mathrm{mg}$ of $\beta$-carotene per $100 \mathrm{~g}$, which is only $1 \mathrm{mg}$ less than the daily intake. Also, it is $80 \%$ balanced by the content of vitamin B6 (pyridoxine), which is involved in the metabolism, necessary for the normal functioning of the central and peripheral nervous systems.

Parsnip contains more vitamins $\mathrm{B}_{1}, \mathrm{~B}_{2}, \mathrm{~B}_{3}, \mathrm{~B}_{5}, \mathrm{~B}_{9}$ and $50 \%$ provides the body's need for ascorbic acid (contains $30 \mathrm{mg}$ per $100 \mathrm{~g}$ ), which is important for the growth and restoration of tissue cells and promotes the absorption of iron by the body [15].

The results of the analysis indicate high indices of the nutritional and biological value of these types of raw materials and confirm the feasibility of their use for the production of candied fruits and cottage cheese with candied fruits. But in the process of heat treatment at the preparation of candied fruits, it is necessary to use heat treatment less than $60{ }^{\circ} \mathrm{C}$ to maximize the preservation of useful properties.

The next stage of the research was the determination of the physicochemical parameters of the curd mass. For the analysis, only samples that received the highest scores (4.9-5) in the process of organoleptic evaluation were used: with candied parsnip (S2) and a sample with candied pumpkin (S4). The results of the assessment of physicochemical parameters of the curd mass are presented in Table 4.

Table 4

Physicochemical characteristics of the cottage cheese mass

\begin{tabular}{lcccc}
\hline \multicolumn{1}{c}{ Indicators } & $\begin{array}{c}\text { Control } \\
(\mathbf{C})\end{array}$ & $\begin{array}{c}\text { Sample with candied parsnip } \\
(\text { S2) }\end{array}$ & $\begin{array}{c}\text { Sample of candied pumpkin } \\
\text { (S4) }\end{array}$ & Norm \\
\hline Acidity, ${ }^{\circ} \mathrm{T}$ & 151 & 155 & 153 & $150-230$ \\
Mass content of sucrose, \% no more & 7.3 & 4.3 & 4,7 & 5 \\
Mass moisture content, \% no less & 65 & 64 & 67 & 78
\end{tabular}

Under the conditions of the experiment, the control sample was prepared strictly according to the recipe, but as a result of the analysis of physicochemical parameters, it was revealed, that when using the "Pineapple" candied fruit of the "Silk Way" trademark (Ukraine), the mass content of sucrose in the curd mass exceeds the standard indicators in accordance with GOST 31680-2012.

The obtained samples with candied parsnip $\left(\mathrm{O}_{2}\right)$ and candied fruit from pumpkin $\left(\mathrm{O}_{4}\right)$ do not correspond to DSTU 4503:2005 by the physicochemical index (mass fraction of sucrose). The mass fraction of sucrose in the curd with candied parsnip is less than the norm by $0.7 \%$, in the curd with candied pumpkin -less by $0.3 \%$. It was in these samples that we made changes in the ratio of prescription components, namely, sugar was not used. Considering the results of the organoleptic evaluation of the obtained samples and not a significant deviation (less than $1 \%$ ) of the mass fraction of sucrose from the normative indicators, it can be concluded, that it is permissible to use the recipe for cottage cheese with candied fruit without sugar. However, appropriate technical terms must be developed for the industrial production of this type of product.

Physicochemical parameters of almost all samples were within normal limits, with the exception of one. In the control sample with candied fruits "Pineapple" (K), the mass content of sucrose was $2.3 \%$ higher than normal. This is due to the high sugar content in candied fruits themselves, as well as the large amount of sugar, provided for in the recipe.

To assess the rheological properties, namely, the density of the structure of the curd mass, the boundary shear stress was determined using a penetrometer. The results showed that all samples have a plastic structure that is smeared: in the control sample $(\mathrm{K}) \sigma=305 \cdot 10^{-2} \mathrm{~Pa}$; in the sample 
with candied parsnip (S2) $\sigma=316 \cdot 10^{-2} \mathrm{~Pa}$; in the sample with candied pumpkin (S4) $\sigma=295 \cdot 10^{-2} \mathrm{~Pa}$. Thus, it is proved, that the proposed types of fillers positively affect the consistency of the product, it remains homogeneous, moderately dense, with the visible and tangible presence of candied fruits. Candied pumpkin has a less elastic fiber structure, therefore, the shear stress of the curd mass with these candied fruits is less. Despite this, the structure of the curd is plastic, which meets the requirements of the standard.

\section{Conclusions}

The cottage cheese mass recipes with candied parsnip and pumpkin have been developed, and the optimum amount of fillers has been determined by organoleptic evaluation $-15 \%$ of the total cottage cheese mass (without additional sugar).

A study of the chemical composition of pumpkin and parsnip showed that it is advisable to use candied fruit from them as fillers, since they contain vitamins, minerals and other necessary elements. The use of $100 \mathrm{~g}$ of candied parsnip provides the body's need for ascorbic acid by $50 \%$, and the consumption of candied pumpkin by $80 \%$ - vitamin B6 and $60 \%-\beta$-carotene.

Physicochemical characteristics of the curd mass with candied parsnip and pumpkin meet the requirements of DSTU 4503:2005 "Curd products. General specifications "for all indicators, except for the mass fraction of sucrose. The mass fraction of sucrose in samples with candied parsnip is $0.7 \%$ less than normal, with candied fruit from pumpkin - less than normal by $0.3 \%$. Thus, in the production of cottage cheese with candied parsnip and pumpkin, you must either use the recipe proposed in GOST 31680-2012, or develop new technical conditions, in which the sucrose mass fraction will be reduced, taking into account the taste preferences of consumers.

Candied fruits from parsnip and pumpkin positively affect the density of the curd mass structure and provide the plastic structure of the product. At the same time, the consistence of the curd is homogeneous, tender, plastic, moderately dense, with visible or tangible presence of the introduced components, which meets the requirements of GOST 31680-2012 and DSTU 4503:2005.

\section{References}

[1] Moiseyeva, L., Romanchuk, I., Rudakova, T. (2015). Enhancement of biological value of cultured milk products intended for child nutrition. Zbirnyk naukovykh prats Vinnytskoho natsionalnoho ahrarnoho universytetu, 2 (1 (82)), 94-98.

[2] Khodjaeva, U., Bojňanská, T., Vietoris, V., Sytar, O. (2013). About food additives as important part of functional food. Journal of Microbiology, Biotechnology and Food Sciences, 2, 2125-2135.

[3] Golubeva, L. V., Dolmatova, O. I., Bandura, V. F. (2015). Studying the properties of quark products with components of plant origin. Vestnik Voronezhskogo gosudarstvennogo universiteta inzhenernyh tehnologiy, 2, 108-111.

[4] Subbotina, M. A., Kolesnikova, T. G. (2009). Tvorozhno-rastitel'nyy produkt gerodiyeticheskogo naznacheniya. Tekhnika i tekhnologiya pishchevykh, 2, 33-36.

[5] Stetsenko, N. A. (2016). Development of sweet creamed curds with vegetable additives for the elderly. Problemy stareniya i dolgoletiya, 25 (2), 280-286.

[6] Sevastianova, O. V., Pylypenko, L. M., Makovska, T. V., Honcharov, D. S. (2018). Nezhyrni syrkovi deserty z roslynnymy biokorektoramy. Vcheni zapysky Tavriyskoho natsionalnoho universytetu imeni V. I. Vernadskoho. Seriya: Tekhnichni nauky, 29 ((68) 2), 272-278.

[7] Hachak, Y., Slyvka, N., Gutyj, B., Vavrysevych, J., Sobolev, A., Bushueva, I. et. al. (2019). Effect of the cryopowder "beet” on quality indicators of new curd desserts. Eastern-European Journal of Enterprise Technologies, 1 (11 (97)), 52-59. doi: https:// doi.org/10.15587/1729-4061.2019.154942

[8] Casarotti, S. N., Penna, A. L. B. (2015). Acidification profile, probiotic in vitro gastrointestinal tolerance and viability in fermented milk with fruit flours. International Dairy Journal, 41, 1-6. doi: https://doi.org/10.1016/j.idairyj.2014.08.021

[9] Bolgova, N., Honchar, A. (2019). Justification of the formulation for cheese paste with cumin. Food Resources, 7 (13), $44-50$. doi: https://doi.org/10.31073/foodresources2019-13-04

[10] Dzyuba, N., Valevskaya, L., Atanasova, V., Sokolovskaya, A. (2017). Elaboration of the recipe of the fermented milk dessert for child food. EUREKA: Life Sciences, 4, 3-9. doi: https://doi.org/10.21303/2504-5695.2017.00371

[11] Mayorov, A. A., Buzoverov, S. Y., Suray, N. M. (2016). Investigation of characteristics of cottage cheese enriched with food fibres. Technology: Chemical technology: Food processing and manufacture, 41 (2), 62-66. 
[12] Slyvka, N. B., Bilyk, O. Y., Mikhailytska, O. R., Nagovska, V. O. (2019). Improvement of technology of curd products with succade from pumpkin. Scientific Messenger of LNU of Veterinary Medicine and Biotechnologies, 21 (92), 47-52. doi: https:// doi.org/10.32718/nvlvet-f9209

[13] Zyablitseva, M. A., Dolmatova, I. A. (2013). Vliyanie ovoschnyh tsukatov na kachestvo i bezopasnost' yogurtov. Aktual'nye problemy sovremennoy nauki, tehniki i obrazovaniya: materialy 71-y mezhdunarodnoy nauchno-tehnicheskoy konferentsii, $1,255-258$.

[14] Josipović, R., Medverec Knežević, Z., Frece, J., Markov, K., Kazazić, S. (2015). Nutrition Quality and Microbiological Safety of Novel Cottage Cheese. Food Technology and Biotechnology, 53. doi: https://doi.org/10.17113/ftb.53.04.15.4029

[15] Golubkina, N. A., Fedorova, M. I., Stepanov, A. N., Nadezhkin, S. M. (2014). Content of micro- and macro-elements of parsnip (Pastinaka Sativa L.). Vegetable Crops of Russia, 3, 18-21. doi: https://doi.org/10.18619/2072-9146-2014-3-18-21

[16] DSTU 4503:2005. Izdeliya tvorozhnye. Obschie tehnicheskie usloviya (2006). DP «UkrNDNTS», 14.

[17] GOST 31680-2012. Massa tvorozhnaya «Osobaya». Tehnicheskie usloviya (2014). FGUP «Standartinform», 8.

[18] Golubkina, N. A., Fedorova, M. I., Stepanov, A. N., Nadezhkin, S. M. (2014). Content of micro- and macro-elements of parsnip (Pastinaka Sativa L.). Vegetable Crops of Russia, 3, 18-21. doi: https://doi.org/10.18619/2072-9146-2014-3-18-21

\title{
INVESTIGATION OF THE INTENSIVE TECHNOLOGY OF FOOD SPROUTS USING ORGANIC ACIDS
}

\author{
Olena Kovaliova ${ }^{1}$ \\ livre@i.ua \\ Yuriy Tchursinov ${ }^{1}$ \\ agro-1@mail.ru \\ Viktoriia Kalyna ${ }^{1}$ \\ viktoriya-kalina@ukr.net \\ Tatyana Khromenko \\ Internet Agency Msystem \\ 10 Mikhail Grushevsky str., Dnipro, Ukraine, 49000 \\ Tat5Ka2687@gmail.com

\section{Ekaterina Kunitsia} \\ Kharkov Trade and Economic Institute of Kiev National Tradeand Economic University \\ 8 O. Yaroshlane, Kharkiv, Ukraine, 61045 \\ ekaterina.kunitsia@gmail.com \\ ${ }^{1}$ Dnipro State Agrarian and Economic University \\ 25 Serhiia Efremova str., Dnipro, Ukraine, 49600
}

\footnotetext{
Abstract

The features of the intensive technology of getting food sprouts with organic acids as an intensifier of germination were studied. The aim was to establish the features of the intensive technology of producing sprouts of different crops with using organic acids at germination (butanedioic, 3-pyridine carbonic, pteroylglutamic). It is important to search new and safe germination stimulators of universal use. Such substances are just the studied organic acids, because positive changes of quality parameters of a ready product are traced at their use in the sprout technology. There was studied the sprout technologies that includes washing, disinfection, step-by-step air-water soaking of grains from different crops and their germination. As a disinfectant and growth stimulator at the stage of grain material soaking, there were used water solutions of the organic acids in the concentration diapason from 0.025 to $2.5 \mathrm{~g} / 1$. Due to their
} 